\title{
The Impact of Education in Combating the Development of the Trafficking in Human Beings Process
}

\author{
Arjeta Shaqiri Latifi
}

PhD Cand. South- West University” Neofit Rilski” Blagoevgrad, Bulgaria

\section{Abstract}

This research will discuss the impact of education on combating the development of the process of trafficking in human beings, as a growing phenomenon in Kosovar society. Trafficking in human beings is a violation of fundamental human rights, a negative phenomenon, as well as a concern and a danger to the whole society. Kosovo is a country in transition, where trafficking in human beings is a great challenge to Kosovar society, especially bearing in mind that this phenomenon developed in the post-war years in Kosovo. The phenomenon of trafficking in human beings dates back to the early days of humanity (from the slave-owner society), but now the forms and patterns of trafficking have changed, transforming into "modern slavery". This phenomenon has become a concern of Kosovar society, which is constantly making great (institutional) efforts to combat this phenomenon. Among the most relevant factors for combating trafficking in human beings is education as a basic factor of a healthy society, which shapes the personality of young people and builds the foundations of a vital society which builds its future on social values and fights trafficking with human beings. Thus, the role of education in a society, as well as the path towards combating the process of trafficking in human beings is analyzed by: family, education, social circle, tradition, community culture, state policies and other competent accompanying institutions. The thesis of this research will be: How does education impact on the fight against the evelopment of the process of trafficking in human beings in Kosovo society? Many authors have given different opinions about education as a factor in combating trafficking in human beings and its impact on society, which will be discussed below. Thus, the paper tends to concretize the impact of education on prevention of trafficking in human beings, where the interview method was used, which was conducted with the competent education officials. As a result of a country with a low level of economic development, high level of poverty, inadequate quality of education, shortcomings in social policies, dysfunctional level of legal infrastructure, we conclude that all these influential factors in combating the phenomenon of trafficking with human beings, remain a constant task for their improvement in our society.

Keywords: youth, education, family, society, trafficking 


\section{Introduction}

\section{Presentation}

Kosovo $^{1}$ is the youngest country in the Balkans which did not face the same negative phenomenon of trafficking in human beings in the period before 1999 (when it was an integral part of the SFRY). in the Balkans which did not face the same negative phenomenon of trafficking in human beings in the period before 1999 (when it was an integral part of the SFRY).

Kosovo has an area of 10,905.25 km, with a population of over 1.782115 inhabitants.

Kosovo is located in the part of south-eastern Europe bordered by Albania in the south-west, Montenegro in the north-west, Serbia in the north-east and Northern Macedonia in the south (Agency, 2018).

Different ethnicities ${ }^{2}$, live in Kosovo, their coexistence is regulated by the constitution and other general legal acts as well as by social welfare policies ${ }^{3}$.

However, the economic situation in Kosovo is unstable, with a low level of economic development, high unemployment rate about $29 \%$, severe poverty and high emigration rates abroad ${ }^{4}$.

The population of Kosovo has an average age of 26 years, while $38 \%$ of the population is under the age of 20 and only $8 \%$ are over the age of 65 .

So, the population of Kosovo is the youngest in Europe, while it has the lowest standard of living in Europe.

Kosovo is populated mainly by ethnic Albanians, but in Kosovo live about $9 \%$ of members of other nationalities, who constitute a diversity of national entities 5 .

In Kosovar society there are social differences which are expressed through; education, culture, tradition, religion, geographical distribution, wealth, employment, participation in government, etc.

Under this social, geographical, economic, political environment, social coexistence develops, with different distinctions in life development and social integration.

\footnotetext{
${ }^{1}$ On February 17, 2008, the Assembly of Kosovo approved the declaration of independence declaring Kosovo an Independent and Sovereign State.

${ }^{2}$ According to KAS (Kosovo Agency Statistics) Albanian ethnicity belongs to 68\%, Serbs24.1\%, others $7.9 \%$ (this includes Turks, Muslims, Croats, Roma, and Egyptian Ashkali).

${ }^{3}$ According to KAS, social protection schemes are ranked: social assistance scheme, scheme of families of martyrs and war invalids, pensions, basic, contributory pensions, etc.

${ }^{4}$ The number of Emigrants in 2019 according to the Kosovo Agency of Statistics was 34,911 including legal and illegal emigrants. Legal emigration was: family reunification, marriage, education, employment

${ }^{5}$ The following entities live in Kosovo: Albanians, Serbs, Roma, Ashkali, Egyptians, Croats, Turks. No problem has emerged even though they live in the same towns, villages and neighborhoods .
} 
Kosovo is a young state, with aspirations ${ }^{1}$ for development of democracy, which is comitted that fundamental human rights will be respected, where every citizen of Kosovo, regardless of nationality, gender, race, religion, has the right to live freely and with dignity throughout the territory of Kosovo.

Special attention is paid to minorities, (Roma, Ashkali and Egyptian communities) who have educational tendency, cultural, traditional, etc. to live as separate communities (Office, 20162020), not being strongly integrated in Kosovo society.

According to the Action Plan Strategy 2016-2020 of the Ministry of Labor and Social Welfare of Kosovo, the areas of cooperation of minority communities are defined in: education, employment, social protection, health and housing (Office, 2016-2020).

The problem of the phenomenon of trafficking in human beings is a very complex phenomenon which takes place mostly under the transnational environment, in a society or state not well consolidated, in which traffickers find space and conditions for the development of this phenomenon, because conditional factors (poverty, education, religion, lack of information, unemployment, stagnation of economic development, lack of a legal framework, demographic culture, gender inequality, violence against women, discrimination against children, nonintegration into society) affect the development of this ugly phenomenon which degenerates society.

Therefore, the task of Kosovo institutions is to combat this phenomenon by regulating the legal framework, organizing the respective professional institutions, minimizing poverty, regulating access to education for all, allowing belief in religion, enabling competent and reliable information, minimizing unemployment, increasing economic development, improving demographic culture, regulating gender equality, fightimng violence against women, eliminatiing discrimination against children, enabling positive integration in society, etc.

\section{Theoretical discussion of the impact of education in society}

The general history of education begins with the organization of school institutions and the educational process, since the time of antiquity.

Under the conditions of development of the slave-owning system, education had an important role in raising the education of people, which was done by the ancient philosophers; Socrates, Plato, Aristotle, etc.

They had educated the youth according to the demands of the slave owners (according to the interests of the ruling class), whereas later, the needs for a comprehensive system of education of children from a young age appeared, who would have to acquire the necessary knowledge in order to master different professions.

In the era of the feudal system, teaching in the middle ages was dominated mainly by the teachings of ecclesiastical dogmas, developed by teachers, with the aim of educating children about life after death.

\footnotetext{
${ }^{1}$ The Constitution of the Republic of Kosovo pays special attention to minority communities living in Kosovo
} 
This is how children were prepared to obey the lessons they were given.

The flourishing of pedagogical education and thought developed in the Renaissance ${ }^{1}$, where humanists insisted that education be made compulsory for all children, in order to enrich the content of the curriculum and the advancement of the curriculum according to the importance, needs and opportunities of the capitalist society.

In the Renaissance period, the Czech pedagogue Jan Amos Komenski was distinguished (15921670), who had contributed to the realization of concepts and views on the mass inclusion of children in education.

Jan Amos Komenski deserves merits the introduction of the class-hour-subject system, treatment of some pedagogical principles, and development of the pedagogical concept which is not excluded from the influence of religion (especially in the field of moral education).

Regarding theoretical treatment of education, many opinions have been given and many theories have been written, starting from the definition of the schooling process and the school institution.

Émile Durkheim (Giddens, 2006) gives the theory of the usefulness of learning social rules and knowledge, arguing that education plays an important role, and especially learning history helps children to benefit and understand the values of society, by uniting special people.

Education influences the acquisition of social rules and contributes to the more efficient functioning of society.

He argued that, in traditional societies, children learn skills within the family, while in industrial societies education helps children to socialize and enables children to get profiled.

While Talcott Parsons (Giddens, 2006) gives the theory of institutional education, through which he had expressed his concerns about individual education (he was concerned about how France in the nineteenth century had developed the individual education) and argued the role of education in social, respectively, institutional solidarity.

He believed that education could not be taught at home ${ }^{2}$, but should be taught in relevant educational institutions. Institutional education was described as an individual achievement, which affects the functionality of industrial society.

Thus, children achieve their status of meritocracy in public educational institutions (Giddens, 2006) , by being taught, tested, and evaluated regardless of class, race, and gender.

Whereas, Bernstein (Giddens, Sociology, 1997) gives the theory of systematic changes in education, through which he presents a series of theoretical perspectives on the consequences of modern education and inequalities, presenting some theoretical perspectives.

\footnotetext{
${ }^{1}$ In this period were especially prominent Vitorino da Feltre, Erasmus of Rotterdam, Thomas Mori, Jan Amos Komenski. Francis Bacon, etc.

${ }^{2}$ Talcott Parsons thought that the status of the child in the family is only described, as it is achieved on school premises.
} 
In one of his studies he argues that children who come from different societies have different forms of speech developed during childhood ${ }^{1}$.

He had argued the difficulties and conveniences that children have, particularly those who are faced with the demands of academic education and adaptation to school environment.

On the other hand, Ivan Illich (Giddens, Sociology, 1997) develops the theory of passive consumption in education and sees education as a passive consumption of a secret curriculum. He argues that education can be learned at any time and by anyone, depending on the circumstances of the beneficiary, he does not consider it as an inevitable opportunity to gain knowledge about a phenomenon or occurrence ${ }^{2}$.

So, knowledge cannot be considered as something one-dimensional, it must be viewed from many aspects, from the aspect of subjectivism and objectivism ${ }^{3}$.

Since both of these approaches to knowledge exist and have their own significance, it is essential that in social sciences and educational research many approaches are defined as objectivistic in the principle of generality.

Whereas, approaches to better research are used and described as subjective or individual, this happens when researchers are dependent on the context of the study (general situation) (Giddens, Sociology, 1997).

So, objectivistic knowledge is knowledge without a known subject, it transcends the individual and has to do with the general (Grenfell, 1998).

While Bordieu (Grenfell, 1998) tries to give arguments about effective education through the theory of applying knowledge in practice. His aim was to try to find a stronger, more objective and more general theory.

The purpose of this theory is not only to explain the logic of social action, including education, but also the inclusion and practice of research.

And this theory has to do with the way of understanding culture, and the way of organizing society.

Kimbal Young (Pal, 2013)gives the theory of socialization through education.

He tried to argue the process of educating children as a possibility of socialization, where children learn social habits, basics, laws, other characteristics of their culture, crafts and various habits which help them to become active members of society.

\footnotetext{
${ }^{1}$ Bersnstein was focused on systematic changes, ways of using language, comparing poor and rich children.

${ }^{2}$ Ivan Illich suggests that the material resources of knowledge be stored in libraries, laboratories, and be available to students, so that when they need them, they have the opportunity to use them to learn the necessary material.

${ }^{3}$ The subjective aspect of knowledge refers to individual knowledge, while the objective aspect of knowledge has to do with access to public knowledge.
} 
The process of socialization of children enables them to develop social actions, making them suitable to their family, neighbors, and community where they live, transmitting the way of acquiring knowledge and developing life relationships in society.

Thus, education creates a social, innovative culture which is transmitted to children through curricula, adapted to sociological and psychological developments as advantage for proper integration in society and in step of technical-technological developments.

So, culture refers to knowledge, ideas that are part of human activity, therefore understanding culture should reflect in education and research.

Some of these theories were regarded as utopian views, unsuitable for changing societal relations, employment relations, and avoiding the many limitations of socio-economic development.

Therefore, with integration of information technology in society and through creation of educational platforms, education is shifting to web developers and information controllers (Giddens, Sociology, 2009).

\section{Methodology}

While working in this paper, (the impact of education in combating the development of the process of trafficking in human beings in Kosovo society) the methods below were used; descriptive, historical, deductive, and empirical.

Whereas, for the instrument of the empirical method was used the interview.

In order to obtain empirical data, the questionnaire was prepared and provided to the competent respondents in the field of education, in order to make a direct observation which, through their experiences, can be analyzed in qualitative views about this phenomenon.

It was intended to qualitatively explain the development of this phenomenon and the possibility of combating it, by defining empirical questions and concrete answers.

The research design is focused on various areas of education as well as the respective social policies in Kosovo, so that the problem can be studied from many angles.

The diversity and distribution of respondents contributed to the presentation of relevant data in thisstudy. Also, included in the research are secondary data, which originate from the responsible institutions of Kosovo1. The study included 40 respondents coming from different fields such as: Ministry of Education, Science and Technology, Media Commissariat, High Schools, Lower Secondary School, Preschool Institutions and Civil Society.

Based on the collection and organization of empirical facts, the hypothesis was tested through deduction (using general data, to come to specific results), which thus verified the unchanged variable.

So, based on the predictions and the tendency of the development of the problem, the evaluation of the the test result was made.

${ }^{1}$ Ministry of Labor and Social Welfare of Kosovo. 
Therefore, using these methods, the state of the problem was reflected, the tendency of its development and the possibilities of its minimization, based on the assessments which have resulted from the measurements of the situation and the analysis of the process in preventing the development of this phenomenon in Kosovar society.

\section{Education}

"Education is better safeguard of liberty than a standing army"- Eduard Everett

"Education is social process. Education is growth. Education is, not a preparation for life; education is life itself -John Dewey".

The first forms of organized learning (in educational institutions) in Kosovo date back to the time of ancient Illyria. The education system in ancient Illyria had included several age groups of children and adults.

In Albanian society it is proven that the presence of educational institutions dates back since the antique periods until the time of the Albanian principalities in the middle ages, then continues in the years of Ottoman occupation (teaching the Albanian language was done secretly from 1584 in a few schools) as a religious teaching until the XIX century ${ }^{1}$.

Whereas, since the XIII century, Kosovo was occupied by the Ottoman Empire and during this period religious education was developed in religious institutions (in mejtepe, madrasas, etc.).

This way of teaching continued throughout the seventeenth and eighteenth centuries, when there was a more rapid development of Islamic schools (mejtepes, madrasas, tekkes, etc.); Albanian was also taught and taught.

As a result of the penetration of European Enlightenment ideas in the Ottoman Empire, secular teachings (non-religious; ethics, mathematics, geography, history, astrology, biology, physics, etc.) were taught in these educational institutions.

After the definitive withdrawal of Turkey from Kosovo (1912), the education system in Kosovo became reoccupied with the Albanian intellectuals, who in 1917 held the "Congress of Teachers of Kosovo", aimed at expanding the school network in Kosovo ${ }^{2}$.

Later, the "Cultural Association of Teachers of Kosovo" was established, which had merged with the Cultural and Educational Association "Besa Kombëtare" based in Gjakova.

Thus, in 1917, there were two teaching courses in Mitrovica and Peja.

With the creation of the Kingdom of Serbo-Croatian-Slovenia or the Kingdom of Yugoslavia ${ }^{3}$, the campaign against Albanian education had started, as a result of which 55

\footnotetext{
${ }^{1}$ In the century XVII and XVIII, a more rapid development of Islamic schools, such as: mejtepes, madrasas, tekkes, etc., as a result of the penetration of European Enlightenment ideas in the Ottoman Empire.

${ }^{2}$ School is the place where through activities; students develop and strengthen their values and beliefs. Through dialogue, communication they reflect their imagination, and especially with the variety of activities and the practice of values, they know themselves and are ready to face the fight against trafficking.
}

${ }^{3}$ The Kingdom of Yugoslavia (or the Serbo-Croatian-Slovenian Kingdom), was a state in

Southeast and Central Europe that existed during the period 1918-1939. 
schools in the Albanian language had been closed, with about 4000 students and 100 teachers, and it had stopped the practice of religious rites in the Albanian language ${ }^{1}$.

In Kosovo, during this period, the Albanian population was illiterate.

Whereas, since 1944, the Education Reform in Kosovo had begun, which has gone through several stages:

The first stage (1944-1966) - Education Reform in Kosovo began in 1944 and lasted until 1966, which defined the development of the general education process into 11 years of schooling. During this period, a campaign was launched against illiteracy in Kosovo, which aimed at educating the people through courses.

Second stage (1966 - 1976) - After 1966, the democratization of the education system in Kosovo was advanced and the consolidation of the education system at all levels began. Vocational high schools were also established during this period.

Third stage (1976 - 1991) - is characterized by the influence of politics in education, because the secondary school was reorganized according to the concept of "oriented education in institutions"2, which influenced the change in the practice of profiling students' lessons.

At the same time, the current government in the SFRY had developed many processes of pursuing and excluding many Albanian teachers and experts from their jobs.

Fourth stage (1991 - 1999) - After the abrogation of the autonomy of the then ASP (Autonomous Socialist Province of Kosovo) and the application of the so-called "temporary measures" by the Assembly of the Republic of Serbia in Kosovo, in 1991 many educational institutions in the Albanian language were closed.

Therefore, as a countermeasure that Albanians undertook, was the organization of a parallel education system in Kosovo (independent democratic education system), which aimed to maintain the continuity of work of educational institutions and the educational process under the occupation of SR of Serbia government.

Independent curricula by Kosovo educational institutions were developed in the Albanian language, and new textbooks were published without ideological or political influences. The whole educational process was conducted in "School Homes", voluntarily by teachers under severe conditions of occupation ${ }^{3}$.

${ }^{1}$ The use of the Albanian language in public life was prohibited, the development of teaching in the Albanian language was prohibited and publishing activities in the Albanian language were prohibited.

${ }^{2}$ In 1976, the reorganization of the high school in Kosovo took place, according to the concept of Dr. Stipe Shuvar, where the first two years of high school took place in OSEC (Oriented Secondary Education Center), while the third and fourth year were organized in different profiles according to the definitions of students' affinities.

${ }^{3}$ At this stage, the education system in Kosovo included: 452 full primary schools, 67 secondary schools, 1 university with 14 faculties and 7 high schools, with about 400,000 pupils and students and 21,000 education workers. This system was funded by volunteer work and assistance provided by the Kosovo Albanian diaspora and population. 
Fifth stage (1999 to date) - With the intervention of NATO forces and the administration of Kosovo under UN Resolution 1244, the complete reform of the education system at all levels (MEST, Kosovo Education Strategic Plan 2017-2021, 2016), in accordance with the highest international standards ${ }^{1}$, had begun.

So, Kosovo is paying special attention to education, in order to increase the level of knowledge for the acquisition of techniques and technology, economic development, development of science, culture, raising human morale (to develop more advanced social relationships), raising the level of social etiquette and building universal relations of the citizens of Kosovo.

In Kosovo, communities of different (small) nationalities are integrated in the education system.

Despite numerous efforts by the Kosovo Ministry of Education, Science and Technology, the low school attendance rate of community children remains a concern; Roma, Ashkali and Egyptians, except children of the Serb community (MESTI, 2011).

All these levels of education in Kosovo are compulsory, while higher education is voluntary.

According to the Strategic Plan for Education in Kosovo 2011-2016, during the planning process, seven areas were selected that cover the relevant segments of education in Kosovo: participation and inclusion, management of the education system, quality assurance, teacher development, teaching and learning, vocational training and adult education, higher education.

This system is implemented in the context of the four EU objectives, to address the challenges of vocational education and training which are: making lifelong learning a reality, improving the quality and efficiency of vocational education and training, promoting equality (social cohesion and active citizenship), increasing innovation creativity, including entrepreneurship at all levels of education (MEST, Kosovo Education Strategic Plan 2017-2021, 2016).

The organization of the education system in Kosovo is organized in three alternative forms: formal, informal and non-formal ${ }^{2}$.

\footnotetext{
${ }^{1}$ Education reform was focused on building; mental abilities, professional skills, civic culture and individual and social well-being of the citizens of Kosovo.

The expansion of the compulsory education system for a class was done and the organization of private education as an alternative and competitive in the development of education.

The first step of this system is the establishment of the Department of Education and Science (DASH), which is followed by the creation of legal and professional infrastructure, which should facilitate the radical reform of education (system $5+4+3-4$ in the education of general and vocational education and the Bologna Agreement in higher education)..

$\left.{ }^{2} 1\right)$ Formal education is organized in school facilities with legal curricula from MEST.

2) Informal education is structured as an additional lesson for building the capacity of children, but not necessary
}

3) Non-formal education is structured outside of curricula, programs, additional learning, and additional knowledge of children in various subjects such as: technology, foreign languages, sports activities, etc. 
Every child has equal rights to education, regardless of ability, color, gender, ethnicity, creating a safe environment, maintaining the environment and reflecting disciplinary behavior (MESTI, 2011).

Duty and responsibility of the Ministry of Education is to ensure the quality of education, to develop policies and draft legislation, to promote the non-discriminatory system, to improve the quality and efficiency of education (MESTI, 2011).

Humanity and advanced nations today mostly need unification in education with genuine social values, because through this education can be minimized negative phenomena in society.

Raising awareness of young people through education affects the quality of life and avoids their involvement in negative phenomena in society.

The level of education of children represents the level of culture which is reflected in the community through actions or behaviors in society.

Social stability, civic progress, interpersonal integration, are ensured or nurtured through education.

And this can be achieved with a unity, common interests, cooperation between, family-schoolhigher state instances.

So, the success of young people is influenced by; the quality of the education system, teaching methodology (educational manners), tools of education, access to technical-technological achievements, level of technical-technological development, geographical position, social integration, etc.

Also an important role in raising the level of education is the financial support of youth, to support educational initiatives, in the acquisition of knowledge, in research, in the application of knowledge, in development, etc (MEI, 2017)

In order to increase the level of education in society, it is necessary to work systematically and permanently with young people, by:

1) Making visible the life perspective through education,

2) Affirm knowledge assessment,

3) Giving impetus to developments in science,

4) Concretize theoretical knowledge in practice.

So, the more creative and innovative the education system becomes, the more the values of education increase.

Therefore, quality education should be persistently aimed at, in order to successfully raise educational values and make society more humane.

\section{History of Trafficking in Human Beings in Kosovo}

The geographical position of Kosovo is favorable for economic development, development of communication, respectively for the development of relations with the Balkan countries, which in most cases, Kosovo also serves as a transit (Commission, 2010) country and destination for trade development. 
The people of Kosovo have inherited a culture and tradition of patriarchy which has been dominated until recently in Kosovar society.

Human freedoms in patriarchal society have been limited, but on the other hand have been strongly controlled by the family.

Identity development is a very important factor including active exploration, consistent commitment to morality, specific individual perspectives and aspirations in life (Erikson, 1968).

(Baumrind, Effects of Authoritative Parental Control on Child Behaviour, 1968) defined three parenting styles: permissive style, authoritarian style and authoritative. She defined the relationship in the middle of the dimensional relationship: warmth, care, support and the degree to which parents maintain expectations for children by supervising and controlling them.

Hence, the phenomenon of trafficking in human beings in the patriarchal society has been condemned, and thus in the Kosovar society has been expressed cases of trafficking mainly of minority groups and stigmatized persons.

So, since the previous centuries, trafficking in human beings has started to develop, especially in the period of development of the Slave-Owner and Feudal system.

In the period of the Socialist system in the SFRY (1945-1999) especially in Kosovo, the phenomenon of trafficking in human beings cannot be said to be obvious, because in this period the state had under supervision through employment and social assistance potential cases of trafficking in human beings, thus minimizing the rate of trafficking in human beings, but was not completely avoided.

After the war meanwhile, the International Community (UNMIK and NATO) had administered and secured Kosovo and had begun to develop the transition process in Kosovo.

Under the conditions of transition of the economic-political and social system in Kosovo, where the economy had undergone the privatization process, workers were left unemployed, the private sector had started with a low development and at a slow pace, the rate of economic development was low, the state of Kosovo was not socially consolidated, the demands of young people for employment were high, in Eastern European countries the lines for trafficking in human beings were structured, they were networked in all Balkan countries and beyond.

Thus, the young people of Kosovo were subjected to the influences of external networks of trafficking in human beings, initially the developers of this ugly process were outsiders, later many local people were recruited here, and who started trafficking in human beings.

It must be noted that during the period 1999-2020, this phenomenon was overspread.

While the object of traffickers were children, young girls and boys, adult women, etc., who were used mainly for begging, performing various jobs in the interest of their bosses, for prostitution, etc. ${ }^{1}$

${ }^{1}$ The victims were mainly from Albania, Moldova, Bulgaria, etc. 
In recent years, the trend of child trafficking is increasing. So, human trafficking is a very complex phenomenon and difficult to deal with, as traffickers are constantly finding alternatives to continue their activity (MIA, 2015).

This phenomenon in Kosovo has been a preoccupation for the state bodies of Kosovo, which have a legal obligation to combat trafficking in human beings, as well as to respect the rights and freedoms of the people according to the Universal Declaration of Human Rights ${ }^{1}$ and European Union laws (UN, 1948)

The Constitution of the Republic of Kosovo regulates human rights; personal rights, social and cultural rights, political and economic rights, etc.

According to the "Strategy for the Rights of Children of the Republic of Kosovo 2019-2023", human capital is defined as an essential factor in economic growth, so investing in children is building a more sustainable, more peaceful world by joining the journey of pro- western countries and fulfilling the obligations set out in the Convention on the Rights of the Child. .

The Government of Kosovo considers human trafficking as a global phenomenon, constantly working towards the creation of "Bilateral Agreements" to combat this phenomenon.

Among the countries with which Kosovo has signed a "Protocol of Cooperation" in; the identification, referral and voluntary return of victims of trafficking in human beings are; Albania and Montenegro (MIA, 2015).

However, with the globalization of economic, political and social processes, the movements of people have become easier, they can to move from one country to another.

Life has become more dynamic, the demands for a better life have steadily increased, the opportunities to cope with high levels of poverty have increased, difficult economic situation in poor and developing countries, have become the cause of domestic violence and Divorces of many marriages, as a result of these family problems, have mostly suffered children (victims).

So, these children have become identified objects for traffickers of human beings.

Among the internal factors that affect the fight against trafficking in human beings is the basic cell of the family, where the child is born, raised and educated.

In a healthy family, healthy educational values are created and in an unstable family, problems are created in the education of children, which are reflected in society.

So, as a result of family problems, divorces, poverty, domestic violence, single-parent families, victimization and access to trafficking with these children is very easy for traffickers.

Assessing lack experience in earlier years of adolescence, therefore find it difficult to determine the reference for the future they have the vitality to accomplish everything. As they have a lot of uncertainty they constantly have desires for constant change. But Identity stabilizes during adolescence, this type of moratorium serves to explore and reflect on different personalities, re-evaluating the past. Throughout adolescence seeking identity, self-

1 Trafficking in human beings is a crime which is sanctioned by the relevant legal norms. This is regulated by the "Universal Declaration of Human Rights and Freedoms", which regulates the right of everyone to live free and equal with dignity to all. 
esteem childish personalities are preserved or rejected, finding strengths, analyzing weaknesses and analyzing career choices (Erikson, Childhood and society, 1963).

Human traffickers investigate unstable families, stigmatized children, children with poorly shaped personalities, in order to use them as objects of trafficking.

The principles of social stability, civil progress, peace and interpersonal cooperation are taught mainly through family education and through the education system of a country.

Among the external factors that also affect the education of young people, are educational institutions, religious institutions, vocational training institutions, media institutions and various training centers.

In addition to direct factors; internal and external to combat the phenomenon of trafficking in human beings, state institutions play a special role; Government with economic departments, Ministry of Labor and Social Welfare, NGOs with social profile, Kosovo Police Service, Prosecution, Judiciary, etc.

These institutions are responsible for policy making; social (employment), economicdevelopment, financial, anti-corruption, etc.

The task of state institutions is the inclusion of children and youth in the integrated process of education, vocational training and employment, in order to minimize the phenomenon of trafficking in human beings (OPM, 2018)

\subsection{Situation of trafficking in human beings in Kosovo}

Trafficking in human beings in Kosovo is a serious concern of Kosovar society, although such a negative phenomenon has existed since ancient times, but still exists today.

In today's living conditions in Kosovo, trafficking in human beings is conditioned by many factors, which are damaging human integrity and dignity, developing it as a harmful social phenomenon.

The phenomenon of trafficking in human beings is taking place as a secret war by traffickers against enslaved persons.

Thus, the process of enslavement did not end with the end of the slave-owning or feudal society.

The enslavement of human beings is continuing in the present time, only it has changed the form of human exploitation, as trafficking in human beings, which is an exploitation, ie the illegal trade of human beings.

The process of trafficking in human beings takes place through; recruitment, exploitation, trading, transfer, quick profit control (MEST, 2015).

However, the ways of recruitment by traffickers have constantly evolved, undergone changes and become more sophisticated.

Based on the Criminal Code of Kosovo, "trafficking in human beings" is defined as; recruitment, transportation, shelter or acceptance under threat, as well as other forms of; misleading, coercing, cheating, by giving or receiving payments, to gain the consent of the other person, in order to control and exploit it for profit (Government, 2019). 
The Criminal Code of Kosovo has also defined the term "exploitation", which includes but is not limited to the exploitation of prostitution of others, pornography or other forms of sexual exploitation, almsgiving, services or forced labor, slavery or similar acts, slavery or removal of organs or cells (Government, 2019).

Victims are usually abused for sexual exploitation, forcing children to work hard (begging), house slavery, etc.

Victims can be local and international, children and adults of all ages. Persons of trafficking (victims) are usually stigmatized persons, or persons belonging to families with severe social status, abandoned children, children with health problems, children of communities that lack adequate education for building of stable personality, children with low level of culture, delinquent persons who have committed any illegal act, etc.

Usually these groups of potential victims are; victimized cases and potential trafficking cases to which they belong; rural communities, divorced families, unemployed youth categories, minorities, low-educated or uneducated communities, groups of people with disabilities, females and minors.

Trafficked victims usually suffer various spiritual or physical injuries (mental, emotional, loss of self-confidence, etc.) and they experience with great difficulties the reintegration phase, and can often be recurrent cases.

Trafficking in human beings mainly takes place through deception, luring victims to a better life, or luring them to a better status, career, fame, fortune, etc., which they can gain at home or abroad.

Based on the data from the State Shelter of Kosovo and the cases received within it in the fiveyear period 2013-2018, which has made the division of cases of local, international victims, adults and children, it turns out that the cases of sheltering domestic victims in 2013 were 14 cases, while in 2018 there were 12 cases, which shows that in this category of victims of trafficking in human beings there is a small decrease in cases.

In 2013, 5 cases of international victims of THB (trafficking of human beings) were sheltered, while in 2018, 5 cases were sheltered, which shows that in this category of victims, there is neither a decrease nor an increase of cases. With regards to adult cases, in 2013 there were 11 cases, while in 2018 there were 3 cases, which shows that in this category of trafficking in human beings victims there is a decrease in cases. With regards to cases of children, in 2013 there were 8 cases, while in 2018 there were 14 cases, which show that in this category of victims there is an increase of cases.

Statistics from the state shelter related to cases received 2013-2018

\begin{tabular}{lllll}
\hline Year & $\begin{array}{l}\text { Domestic } \\
\text { cases }\end{array}$ & $\begin{array}{l}\text { International } \\
\text { cases }\end{array}$ & Adult cases & $\begin{array}{l}\text { Children } \\
\text { cases }\end{array}$ \\
\hline 2013 & 14 & 5 & 11 & 8 \\
\hline
\end{tabular}

${ }^{1}$ Based on the data of the above institutions, the victims of trafficking are usually from Moldova, Serbia, Albania, Romania (most are young underage girls who have been exploited for prostitution). 


\begin{tabular}{|l|l|l|l|l|}
\hline 2014 & 19 & 5 & 8 & 16 \\
\hline 2015 & 8 & 3 & 4 & 7 \\
\hline 2016 & 21 & 10 & 13 & 18 \\
\hline 2017 & 26 & 9 & 15 & 20 \\
\hline 2018 & 12 & 5 & 3 & 14 \\
\hline
\end{tabular}

Fig. No.1. Source: State shelter cases received 2013-2018.

It can be considered that children's cases have marked an increase in cases during the period 2013-2018, while in adult cases there has been a decrease in cases, while in the cases of international victims there has been neither a decrease nor an increase in cases. .

According to the data of the shelters of local victims of adults and children, it turns out that in the cases of sheltering of local victims there has been a small decrease of cases.

So, it can be concluded that the situation of trafficking in human beings has undergone changes within the period 2013-2018 as a result of the action of operating mechanisms in preventing trafficking in human beings.

Preventive measures to combat trafficking in human beings are focused on social support of categories of society (which are endangered and potential cases of trafficking) through the organization of Social Schemes (Shaqiri, 2012), categorized into two groups:

a) The first category - provides poor families with financial assistance, who have no member who is able to work or do not expect to be able to work and who have at least one child under the age of five.

b) The second category - provides poor families with financial assistance, who have members able to work but who are currently unable to find a job.

\section{Research results}

According to the questionnaire, especially the first question: Do you think that care and education have an important role in raising citizens' awareness to combat the development of trafficking in human beings? All respondents (100\%) of them strongly believe that Education has important role in raising awareness to combat the development of trafficking in human beings.

In the second question: The best educational relationships are built through: $(75 \%)$ of respondents think that education built through Family, (17.5\%) by Various educational institutions and only (7.5\%) through Social networks.

Regarding third question: Child care and education is an organized social activity, based on the rights of children and aims to: (37.5\%) think child care and education is an organized social activity to Promote intellectual development, (32.5\%) determinate Encouraging social integration while (27.5\%) opinion was Maintaining health and only $(2.5 \%)$ think that child care and education Improving health.

According the fourth question: For the care, education of preschool children, should be responsible: (65\%) of respondents opinion is care and education of preschool children should 
be responsible parents-family, (27.5\%) Local governments responsible for implementation of education policies, while (7.5\%) Community they live with.

At the fifth question: Should childcare institutions (kindergartens) be obliged to provide minimum standards for every child, on equal terms, without any form of discrimination, ensuring that: Conditions for normal development of each child (90\%) opinion was, and only $(10 \%)$ of them thought was differentiated conditions for stigmatized children.

At the sixth question: Children with disabilities are entitled to individual support and an individualized approach: Most of them (37.5\%) think that involvement in the educational process and in various processes in society of children with disabilities, while $(32.5 \%)$ think to have special educators and (30\%) opinion is not to be distinguished from the treatment of other children.

In the seventh question: Awareness of parents, members of professional services and educators should focus on: (37.5\%) think that above entities should provide a stimulating environment for development, (30\%) Involvement of children with disabilities in kindergartens and schools, (20\%) development of respective educational programs and $(12.5 \%)$ ensuring sufficient quality of life.

Following with the eighth question: Which of these internal factors is most affected by family education in children, vs. adolescents? (50\%) of respondent are determinate for Family status (respect status) that has influence in children education, while (32.5\%) opinion was Personality (personality formation), and (17.5\%) think that Family education affect in identity (developing a sense of identity).

Regarding to nine question: What aspects can be improved through educating the young person vs. adolescents? From all respondents (42.5\%) think that educating of young person vs. adolescents go through Qualitative or substantive aspect of development, (35\%) think, and only (2.5\%) the Aspect of information on the perspective derived from artificial intelligence. Quantitative aspect of development (increase and improvement of cognitive skills of children), (12.5\%) the Aspect of explaining the development of cognitive skills in terms of increasing the specific components of the thinking process, (7.5\%) think Aspect of life safety.

Going through the tenth question: To which categories of persons should the importance of education on the prevention of trafficking in human beings be given, persons with? From all respondent $(25 \%)$ think importance of education on the prevention of trafficking in human beings go through Intellectual maturity, (22.5\%) Physical maturity, (15\%) Sexual maturity, $(12.5 \%)$ maturity (being aware of the right time, place and moment) another (12.5\%) Moral maturity, (10\%) Psychological maturity (ability to respond to the environment in an appropriate way), and only (2.5\%) think for Physiological maturity of the organism and result of the maturation process.

According eleventh question: Motivation or inhibition of the development of adolescents' individuality is expressed through; Moreover of respondents (42.5\%) for motivation or inhibition of development of adolescents acquisition chose of Family values, therefore keep parents for a long time as "moral leaders", while (35\%) Creating the concept of self, keeping a conscious attitude beyond the capabilities, and (22.5\%) Outbreak of internal and external conflict, expressed or silent, which occur for the objective and subjective reason. 
In the twelve question: What is the best way to educate a child, a teenager in building his personality, so that they do not fall prey to trafficking in human beings? (45\%) think best way to educate a child in building his personality and to not fall prey of trafficking is to Identifying individual psychological difference and encouraging their understanding and acquisition, (25\%) Complementing the new knowledge of the individual and educating about the development of his psychological processes, (15\%) Willingness for necessary improvements, $(10 \%)$ the Tendency to adapt to human nature, through psychological similarities between individuals, and (5\%) of them Comparing the achievement of current knowledge and the need to learn new knowledge.

Regarding to thirteen question: What are the external influencing factors that influence children-adolescents to prevent trafficking in human beings? Most of respondents (37.5\%) opinion for external factors identified School, teaching scientific knowledge interviewed with culture, (17.5\%) from Peers, (15\%) the Example that young people take from the people around them (parable of an old man and another (15\%) Social media and networks (Positive $\leftrightarrow$ negative examples, copying models from the internet as well as uncontrolled materials) and the end (5\%) of them identified Society, the "idol" phenomenon, finding a common language.

Regarding the fourteenth question: What are the most preventive measures that can affect education to prevent trafficking in human beings in society? Respondents answer about preventive measures that can effect in education in order to prevent trafficking, (45\%) Awareness, (30\%) Information, and (25\%) Education.

According the fifteenth question: How do you think the state education authorities and the rest of society have responsibly committed themselves to human trafficking? Two groups of respondents by (35\%) think responsibility of state education authorities is insufficient and others on the average, and (30\%) think that state authorities' responsibility is enough.

In the last question: How coordinated are the relations between the responsible State Institutions, Family and School, Religious Institutions, Media and Civil Society in the process of educating young people, as an opportunity to prevent trafficking in Kosovo society? (52.5\%) of them think that coordination between State Institution-Family- School, Religious Institutions, Media and Civil Society are Enough (35\%) think Insufficient and (12.5\%) are Good.

\section{Findings}

The purpose of this research was to analyze and describe the importance of education in raising awareness towards combating trafficking in human beings.

The role and impact of education has been highly praised by all respondents. The care and education of children is an organized social activity, based on the rights of children and aims to promote intellectual development.

The principles of social stability, civil progress, peace and interpersonal cooperation are learned from family education, where identity develops.

Starting from the preschool level where the primary responsibility for the education of the child are the parents and the family.

An important role is also played by state institutions which are responsible for drafting and implementing policies and standards. 
The age which needs a proper education, towards awareness starts from 3-6 years old, not excluding children with special needs ${ }^{1}$.

These children should be provided with a simulated environment for development and have the right to be included in the educational process and in various processes in society.

Awareness of parents, members of professional services and educators should focus on providing a stimulating environment for development.

The family is the cell where the education of the child begins, so as an internal factor which is influenced by family education is the family status (status of respect). This family status affects the creation of personality as well as the mental development towards the creation of the identity of young people (adolescents). Through the education of the person the qualitative or substantive aspect of development (improvement and processing of knowledge. It takes a commitment to pay attention to the personality education of young people (adolescents).

Assessing lack experience in earlier years of adolescence, therefore find it difficult to determine the reference for the future they have the vitality to accomplish everything. As they have a lot of uncertainty they constantly have desires for constant change.

Therefore, education on the prevention of trafficking in human beings should be given importance, first to those adolescents with intellectual maturity and then to those with physical maturity.

Motivation or inhibition of the development of adolescence individuality is done through the acquisition of family values, therefore keep parents for a long time as "moral leaders".

In building the personality of the adolescent, the best way of education is through the Identification of individual psychological differences and the encouragement for their understanding and acquisition.

As for the factors of intellectual shaping, the education of young people should be focused on preventing trafficking in human beings towards general knowledge.

Above we mention the internal factors that affect the prevention of youth trafficking, we now analyze that external factors which have a significant impact on the prevention of this phenomenon. Schools play an important role, teaching scientific knowledge intertwined with culture, not excluding peers, media and social networks where we have positive and negative examples of copying.

An additional element in education and prevention of trafficking in human beings is education and professional training, but it does not exclude the importance of getting to know or socializing with other young people from all over the country.

As always, taking preventive measures that affect education in order to prevent trafficking in human beings plays an important role and that ranks first is awareness and then information.

However, the commitment of the state education authorities and the rest of society, who responsibly committed themselves to human trafficking, is insufficient.

\footnotetext{
${ }^{1}$ Children with disabilities most of the time are stigmatized and not integrated in Kosovar society.
} 
Therefore, there is a need for proper cooperation between the family and the relevant institutions as there is not enough coordination, which play a key role in educating young people towards the prevention of trafficking.

\section{Recomendations}

1. There should be constant awareness and information campaigns towards combating the phenomenon of trafficking in human beings (not only in the designated months).

2. Students must be constantly aware of the negative phenomena, so reforms must be made in education (curricula) in order for this phenomenon to decline.

3. Greater awareness of the youth, especially in the rural parts of the country, especially the families with financial problems, mental and physical problems.

4. Social schemes should be analyzed and reviewed.

5. A cooperation and financing between the Government and NGOs in increasing the funds towards combating this phenomenon.

6. To work continuously with the community to denounce the perpetrators of criminal offenses, to impose heavier sentences.

7. The law should function better towards increasing the level of punishments of perpetrators of criminal offenses.

8. Designation of prosecutors and judges who should attend more advanced training in law enforcement investigations into trafficking prosecutions.

9. To have a common database for all institutions, for cases of trafficking, prosecutions and punishments.

10. Greater attention in television programs (media), awareness also through social networks, considering that the youth are their main users.

11. Significance, greater investment by the government towards reintegration of victims, otherwise recidivism cases will increase.

(Baumrind, Authoritarian vs. authoritative parental control; Adolescence, 1968)

\section{References}

[1] Agency, K. C. (2018). Ministry of Economy and Environment. Retrieved from geoportal.rks-gov.net: https://eurogeographics.org/member/kosovo-cadastralagency

[2] Baumrind, D. (1968). Effects of Authoritative Parental Control on Child Behaviour. Barkley: University of California, p. 887-891.

[3] Commission, E. (2010). Kosovo 2010 Progress Report. Brussels: Europian Parliament.

[4] Erikson, E. H. (1963). Childhood and society. New York: Norton.

[5] Erikson, E. H. (1968). Identity: Youth and crisis. New York: Norton.

[6] Giddens, A. (1997). Sociology. Tirane: Cabej, p. 410-413. 
[7] Giddens, A. (2006). Sociology Fifth edition. Cambridge: Polity Press 65 Bridge Street, p. 686-687.

[8] Giddens, A. (2009). Sociology. Cambridge: Polity Press, p. 877-879.

[9] Government. (2019, January 14). Criminal Code of Republic of Kosovo. Retrieved from Official Gazette https://gzk.rks-gov.net/ActDetail.aspx?ActID=18413

[10] Grenfell, M. J. (1998). Bourdieu and Education: Acts of Practical Theory. London: UK Falmer Press., p 11

[11] Ministry of Europian Integration. (2017, February 20). National Program for the Implementation of the Stabilization and Assotiation Agreement. Retrieved from https://kryeministri.rks-gov.net/repository/docs/Kosovo-EU_SAA_Final_1.pdf

[12] Ministry of Education, Science and Technology. (2015). Bashkohu me ne. Retrieved from Te Parandalojme Trafikimin me Qenie Njerezore: https://masht.rksgov.net/uploads/2015/12/manuali-per-mesuesbashkohuni-me-nete-parandalojmetrafikimin-e-qenieve-njerezore.pdf

[13] Ministry of Education, Science and Technology. (2016, July). Kosovo Education Strategic Plan 2017-2021. Retrieved from http://www.kryeministriks.net/repository/docs/KOSOVO_EDUCATION_STRATEGI C_PLAN.pdf

[14] Ministry of Education, Science, Technology and Inovation. (2011, September 16). Law No.04/L-032 Pre- University Education. Retrieved from Law on Pre University Education in Republic of Kosovo: https://masht.rks-gov.net/uploads/2015/06/1ligji-per-arsimin-parauniversitar.pdf

[15] Ministry of Internan Affais. (2015, MArch). National Strategy Against Human Trafficking in Kosovo 2015-2019. Retrieved from https://kryeministri.rksgov.net/repository/docs/STRATEGJIA_KOMBETARE_KUNDER_TRAFIKIMIT_ME_NJ EREZ_NE_KOSOVE_2015-2019.pdf

[16] Ministry of Internal Affairs. (2015, March). National Strategy and Action Plan Against Trafficking in Human Beings in Kosovo 2015-2019. Retrieved from https://kryeministri.rksgov.net/repository/docs/STRATEGJIA_KOMBETARE_KUNDER_TRAFIKIMIT_ME_NJ EREZ_NE_KOSOVE_2015-2019.pdf

[17] Office Prime Minister. (2016-2020). Strategy and Action Plan for the Inclusion of the Roma, Ashkali and Egyptian Communities in Kosovo Society. Retrieved from http://www.kryeministriks.net/repository/docs/Draft-Strategjia-per-integrimin-ekomuniteteve-2016-2020-.pdf

[18] Office Prime Minister. (2018, December 25). Strategy for the Chlidren Rights 20192023. Retrieved from https://kryeministri.rks-gov.net/documents/strategjia-perte-drejtat-e-femijeve-2019-2023/

[19] Pal, K. (2013). Philosophical and Sociological Foundation. New Delhi, India, Punjab, Phagwara: Laxami Publication (P) Ltd. 113, Golden House. 
[20] Shaqiri, N. (2012). State Social Protection Scheme for Socially Vulnerable Groups in Kosovo, with Special Focus on Trafficking with Human Beings. Pristina.

[21] UN. (1948, December 10). Universal Declaration of Human Rights. Peace, dignity and equality on a healthy planet. Paris, France, France: United Nations https://www.un.org/en/about-us/universal-declaration-of-human-rights. 